\title{
Accomplishing Career Transitions 2019: facilitating success towards the professoriate
}

\author{
Verónica A. Segarra ${ }^{1,2^{*}}$, Jim Vigoreaux ${ }^{1,3}$, Maria Elena Zavala ${ }^{1,4}$ and Ashanti Edwards ${ }^{1}$ \\ From Accomplishing Career Transitions 2019: Professional Development for Postdocs and Tenure-track Junior Faculty in the \\ Biomedical Sciences \\ Chapel Hill, NC, USA. 24-27 June 2019
}

\begin{abstract}
The Minorities Affairs Committee of the American Society for Cell Biology through its Accomplishing Career Transitions (ACT) program aims to ease critical transitions for postdocs and junior faculty from underrepresented backgrounds in STEM or from minority-serving institutions as they work towards promotion and tenure at a wide range of academic institutions. The ACT program is a 2-year cohort-based professional and skills development program that kicks off with a summer workshop and continues with additional online training sessions on selected topics, forging the creation of a permanent mentoring community for the participants. In this BMC Proceedings Supplement, we highlight selected content from the first ACT summer workshop held in 2019 at the Rizzo Center in Chapel Hill, NC. The goal of this BMC Proceedings Supplement is to amplify impact of ACT programming in a way that transcends the ACT Fellow community to benefit an increased number of scientists.
\end{abstract}

Keywords: Professional development for scientists, Tenure-track faculty, Tenure, Professoriate, Professional development practicum, Professional development experiential learning, Accomplishing Career Transitions, American Society for Cell Biology, Minorities Affairs Committee

\section{Background}

The Minorities Affairs Committee (MAC) of the American Society for Cell Biology (ASCB) through its Accomplishing Career Transitions (ACT; https://www.ascb.org/careerdevelopment/2021-accomplishing-career-transitions-actprogram/) program aims to ease critical transitions for postdocs and junior faculty from underrepresented backgrounds in STEM or from minority-serving institutions (MSIs) as they work towards promotion and tenure at a wide range of academic institutions. Scientists from

\footnotetext{
* Correspondence: vsegarra@highpoint.edu

${ }^{1}$ American Society for Cell Biology, Bethesda, MD 20814, USA

${ }^{2}$ Department of Biology, High Point University, High Point, NC 27268, USA

Full list of author information is available at the end of the article
}

underrepresented backgrounds in STEM or from MSIs tend to have less access to mentoring than their peers from well-represented groups or their institutions are under-resourced and cannot provide relevant mentoring and professional development activities, respectively $[1,2]$. The ASCB MAC has a long history in creating professional development programs to help relieve these disparities in access to mentoring and professional development resources [3-6].

The ACT program is a 2-year cohort-based professional and skills development program that kicks off with a summer workshop and continues with additional online training sessions on selected topics, forging the creation of a permanent mentoring community for the

(c) The Author(s). 2021 Open Access This article is licensed under a Creative Commons Attribution 4.0 International License, which permits use, sharing, adaptation, distribution and reproduction in any medium or format, as long as you give appropriate credit to the original author(s) and the source, provide a link to the Creative Commons licence, and indicate if changes were made. The images or other third party material in this article are included in the article's Creative Commons licence, unless indicated otherwise in a credit line to the material. If material is not included in the article's Creative Commons licence and your intended use is not permitted by statutory regulation or exceeds the permitted use, you will need to obtain permission directly from the copyright holder. To view a copy of this licence, visit http://creativecommons.org/licenses/by/4.0/ The Creative Commons Public Domain Dedication waiver (http://creativecommons.org/publicdomain/zero/1.0/) applies to the data made available in this article, unless otherwise stated in a credit line to the data. 
participants. ACT combines five key elements into the framework of what has worked best in past ASCB MAC professional development workshops: 1) Core sessions to help all trainees develop transferrable entrepreneurial skills such as leadership, communication, and negotiation; 2) Modular parallel sessions that allow participants to select the most appropriate session based on their academic career path (e.g. teaching-intensive or research-intensive) and career stage (e.g. postdoc or junior faculty); 3) Customized content in core and parallel sessions to meet the needs and challenges specifically articulated by participant trainees immediately before the summer workshop; 4) Opportunity for skill application through a practicum intended to benefit participating trainees; and 5) Scaffolded expansion of trainees' professional networks, including peer- and near-peer mentors. In this BMC Proceedings Supplement, we highlight selected content from the first ACT summer workshop held in 2019 at the Rizzo Center in Chapel Hill, NC. The goal of this BMC Proceedings Supplement is to amplify impact of ACT programming in a way that transcends the ACT Fellow community to benefit an increased number of scientists.

The topics encompassed in this Supplement are relevant now in 2021 more than ever, as trainees adapt to the effects of the COVID-19 global pandemic crisis in their career trajectories. Topics include effective mentorship, obtaining a faculty position, starting a lab, preparing for tenure and promotion, and professional development through experiential learning. These topics are discussed in the context of both teachingintensive and research-intensive academic aspirations. The authors have grounded their discussion of these topics in relevant literature and resources. Our purpose is to empower trainees with tools to understand success in these areas in the context of their institutions, not as prescriptive, but as unique experiences that they can tune to resonate with their values, personal trajectories and definitions of success.

\section{Abbreviations}

ACT: Accomplishing Career Transitions; ASCB: American Society for Cell Biology; MAC: Minorities Affairs Committee.

\section{Acknowledgements}

We thank the first cohort of ACT Fellows for their participation in the program. We also thank the speakers, panelists, moderators, and program faculty of the ACT 2019 summer workshop.

\section{About this supplement}

This article has been published as part of BMC Proceedings, Volume 15, Supplement 2, 2021: Accomplishing Career Transitions 2019: Professional Development for Postdocs and Tenure-track Junior Faculty in the Biomedical Sciences. The full contents of the supplement are available at https:// bmcproceedings.biomedcentral.com/articles/supplements/volume-15supplement-2.

\section{Authors' contributions}

VAS, JV, MEZ, and AE conceptualized the article. VAS generated a first draft of the article. VAS, JV, MEZ, and AE edited the manuscript and approved the final version. All authors read and approved the final manuscript.

\section{Authors information}

Verónica A. Segarra (ASCB IPERT Co-PI) is Assistant Professor and Interim Chair of the Department of Biology at High Point University, NC. Jim Vigoreaux (ASCB IPERT Co-PI) is the Breazzano Family Green and Gold Professor and Vice Provost for Faculty Affairs at the University of Vermont. Maria Elena Zavala (ASCB IPERT Co-PI) is Professor of Biology at California State University. Ashanti Edwards (ASCB IPERT PI) is Director of Professional Development at the American Society for Cell Biology.

\section{Funding}

The ACT program and the Article Processing Charge (APC) for this article is supported by an Innovative Programs to Enhance Research Training (IPERT) grant from the National Institute of General Medical Sciences (NIGMS) awarded to the American Society for Cell Biology (award number 2R25GM116707).

Availability of data and materials Not applicable.

\section{Declarations}

Ethics approval and consent to participate

Not applicable.

Consent for publication

Not applicable.

\section{Competing interests}

The authors declare that they have no competing interests.

\section{Author details}

${ }^{1}$ American Society for Cell Biology, Bethesda, MD 20814, USA. ${ }^{2}$ Department of Biology, High Point University, High Point, NC 27268, USA. ${ }^{3}$ Department of Biology and Office of the Provost, University of Vermont, Burlington, VT 05405, USA. ${ }^{4}$ Department of Biology, California State University Northridge, Northridge, CA 91330, USA.

Published: 22 June 2021

\section{References}

1. National Academies of Sciences, Engineering, and Medicine. The science of effective mentorship in STEMM: National Academies Press; 2019.

2. Cunningham A, Park E, Engle J. Minority-serving institutions: doing more with less | IHEP: Institution for Higher Education Policy; 2014.

3. Segarra VA, Carrero-Martínez F, Shugart E. The minorities affairs committee of the american society for cell biology_-fostering the professional development of scientists from underrepresented minority backgrounds. CBE Life Sci Educ. 2017:16:1-3.

4. Segarra VA, Zavala M, Hammonds-Odie L. Applied theatre facilitates dialogue about career challenges for scientists. J Microbiol Biol Educ. 2017;18:1-5.

5. Segarra VA, Blatch S, Boyce M, Carrero-Martinez F, Aguilera RJ, Leibowitz MJ et al. Scientific societies advancing STEM workforce diversity: lessons and outcomes from the minorities affairs committee of the American Society for cell biology. J Microbiol Biol Educ. 2020;21:1-7.

6. Segarra VA, Vega LR, Primus C, Etson C, Guillory AN, Edwards A, et al. Scientific societies fostering inclusive scientific environments through travel awards: current practices and recommendations. CBE Life Sci Educ. 2020;19:es3.

\section{Publisher's Note}

Springer Nature remains neutral with regard to jurisdictional claims in published maps and institutional affiliations. 